\title{
Genetic Studies for Yield and Fibre Quality Related Traits in Upland Cotton (Gossypium hirsutum L.) and Identification of Superior Transgressive Segregants
}

\author{
K. Nandhini ${ }^{1}$, N. Premalatha ${ }^{1}$, R. Saraswathi ${ }^{2}$, N. Sakthivel ${ }^{3}$ and N. Kumaravadivel ${ }^{4}$ \\ ${ }^{1}$ Department of Cotton, ${ }^{2}$ Department of Rice, ${ }^{3}$ Central Farm Unit, ${ }^{4}$ Department of \\ Bioinformatics, Tamil Nadu Agricultural University, Coimbatore - 641 003, India \\ *Corresponding author
}

\section{Keywords \\ Transgressive segregants, Cotton, Monopodia, Environmental influence}

Article Info

Accepted:

12 October 2019

Available Online:

10 November 2019
Improvement of agronomic traits and fibre quality in cotton requires detailed information on genetic variation available in the population. The objective of this study was to investigate variability, heritability and character association in nine agronomic and five fibre quality traits among 220 recombinant inbred lines (RILs) derived from MCU 5 and TCH1218. The study was undertaken during kharif 2018-19 at Department of cotton, TNAU, Coimbatore. High PCV and GCV were exhibited by number of monopodia per plant, while moderate GCV and high PCV were recorded by number of bolls per plant. The traits boll weight, single plant yield, lint index and fibre fineness exhibited moderate GCV. Most of traits except five were in similar trend for GCV and PCV indicating less environmental influence. All traits had high heritability, whereas high GAM was expressed for number of monopodia per plant, boll weight, lint index, elongation percentage and fibre fineness. Such traits were additive in nature and process of selection will be effective. Number of bolls per plant and number of sympodia per plant were positively and significantly correlated with single plant yield. In fibre quality, bundle strength and elongation percentage were significantly and positively correlated with upper half mean length. So, while selecting high yielding genotypes these traits are to be considered. Superior transgressive segregants for single plant yield was identified as RIL 44 as it performed better for other yield component traits, while for fibre quality RIL 63 performance was comparatively higher. Among the population RIL 220 ranked top for single plant yield and upper half mean length. Fibre quality traits had few favourable segregants when compared to yield traits. These identified RILs can be used in advance breeding trial for varietal development. 


\section{Introduction}

Cotton is an important commercial crop and 60 percent of industries depend on cotton. India is the second largest producer succeeding China. Cotton contributes about four percent to country's gross domestic product. In India average productivity of cotton is lower compared to all other cotton growing countries in the world. So, breeding programmes should be focused on improving productivity per unit area and simultaneously the fibre quality to meet the industrial demands. Knowledge about genetic variability, heritability with genetic advance for yield, yield related components and fibre quality traits in a breeding population is very much essential for identifying superior recombinants. High heritability with high genetic advance increases the efficiency for response to selection (Larik et al., 1997). A detailed examination about mean performance, extent of association between yield and other agronomic traits is essential for a breeder (Khan, 2003) to select superior genotypes than the existing ones, a continuous process to reach our goals.

Hence the present study was conducted to estimate genetic variability, heritability, genetic advance and correlation for yield, yield related components and fibre quality traits in 220 intra specific recombinant inbred lines (RILs) of $F_{11}$ generation from the cross between MCU5 and TCH1218 to improve the efficiency of selection response. Investigation includes selection of transgressive segregants among RILs to improve the productivity.

\section{Materials and Methods}

Recombinant inbred lines (220) of cross MCU $5 \mathrm{x}$ TCH1218 were sown along with parents and standard check $\mathrm{CO} 14$ in randomized block design with two replications at Department of cotton, TNAU, Coimbatore during kharif 2018-2019. The plant to plant distance was $45 \mathrm{~cm}$ while row to row distance was $90 \mathrm{~cm}$. In each row, 13 plants were maintained. Proper agronomic practices were followed to raise a healthy crop.

From each single row, three plants were selected randomly per replication to observe 14 biometrical traits viz., plant height $(\mathrm{cm})$, number of monopodia per plant, number of sympodia per plant, number of bolls per plant, boll weight (g), single plant yield (g), seed index, lint index, ginning outturn (\%), Upper Half Mean Length (UHML) in mm, uniformity index, elongation percentage, fibre strength (g/tex) and fibre fineness ( $\mu \mathrm{g} / \mathrm{inch})$. Fibre quality traits were measured using STATEX compact high volume instrument. For assessing fibre properties HVI mode was used. The genotypes were classified for fibre traits based on standards specified by Central Institute for Research on Cotton Technology (CIRCOT), Mumbai

The data on quantitative traits were subjected for analysis of variance to know the significance difference. Means for each trait were further separated and compared by means of critical difference at 5\% level of probability. Heritability, genetic advance, phenotypic coefficient of variation (PCV) and genotypic coefficient of variation (GCV) were calculated using TNAUSTAT. Simple correlation was calculated using SPSS version 16.0 .

\section{Results and Discussion}

\section{Variability and heritability}

Analysis of variance showed significant genetic variance for yield, yield related components and fibre quality traits, which indicates selection is effective for these traits and the population possesses adequate variability (Table 1). Moreover, these traits 
fall in a normal distribution curve which reveals that they are polygenic. Number of monopodia per plant exhibited high PCV and GCV. Raza et al., (2016) also obtained similar results in $\mathrm{F}_{4}$ population of upland cotton. Moderate GCV with high PCV were recorded by number of bolls per plant. Many previous studies ensure high variance for number of bolls per plant, which indicates selection can applied to this trait to isolate promising entries (Kale et al., 2007; Erande et al., 2014 and Haq et al., 2017). Number of sympodia per plant, boll weight, single plant yield, lint index and fibre fineness showed moderate PCV and GCV. Some authors have concluded with similar results (Preetha and Raveendran, 2007 and Pujer et al., 2014). Since low PCV with GCV was recorded by plant height and many quality traits viz., ginning outturn, seed index, Upper Half Mean Length, uniformity index, bundle strength and elongation percentage, these traits cannot be used for direct selection. Same results were substantiated by Killi et al., (2005). Most of traits were in similar trend for GCV and PCV with less environmental effect except plant height, number of bolls per plant, boll weight, single plant yield and lint index.

High heritability with high to moderate genetic advance as percent of mean (GAM) was exhibited by number of sympodia per plant, number of monopodia per plant, boll weight, seed index, lint index, elongation percentage and fibre fineness. These traits were additive in nature and selection will be effective. In the studies by Preetha and Raveendran (2007) and Ashan et al., (2015) similar results were encountered. High heritability and low GAM were recorded by plant height, single plant yield, number of bolls per plant, ginning outturn, Upper Half Mean Length, uniformity index and bundle strength. Non additive nature of such traits was also revealed in the experiments conducted by Kale et al., (2007) and Alkuddsi et al., (2013) in upland cotton.

\section{Correlation between single plant yield and other yield components}

Single plant yield was highly significant and positively correlated with two component traits viz., number of sympodia per plant and number of bolls per plant upon which selection may be emphasized. Also, number of sympodia per plant was significantly and positively correlated with plant height and number of bolls per plant which reflected on positive association with yield (Table 2 ).

Ginning outturn was significant and positively correlated with boll weight and lint index, while it was significant and negatively correlated with seed index. Significant and positive association was observed between number of monopodia per plant, boll weight and seed index with lint index. Lint index was negatively correlated with plant height. Seed index was positively associated with boll weight and negatively correlated with number of sympodia per plant.

Significant and positive association was recorded between boll weight and number of monopodia per plant, while number of monopodia per plant was significant and negatively correlated with plant height and number of sympodia per plant. These results were supported by many previous studies (Farooq et al., 2018; Monisha et al., 2018; Deshmukh et al., 2019 and Jarwar et al., 2019) but differ in population structure.

\section{Correlation between fibre quality traits}

Upper Half Mean Length of fibre was significant and positively correlated with bundle strength and elongation percentage (Table 3), while negatively correlated with fibre fineness. Significant and negative association was noticed between fibre fineness and bundle strength. Bundle strength and uniformity index has significant and positive 
association with elongation percentage, while bundle strength was positively correlated with uniformity index. While selecting genotypes with high Upper Half Mean Length, the correlated traits viz., bundle strength and elongation percentage will be automatically selected but fibre fineness may be compromised. Monisha et al., (2018) ended up with similar results in $\mathrm{F}_{1}$ hybrids.

\section{Transgressive segregants for yield and fibre components}

Transgressive segregants for high single plant yield $(>130 \mathrm{~g})$ has been presented along with their performance for component traits (Table 4). The RILs 220, 203, 42, 122 and 44 recorded higher single plant yield of above $130 \mathrm{~g}$. It could be observed none of the RILs possessed the highest values for other component traits. RIL 220 stood first for single plant yield of kapas (149.36g) and also for the significantly correlated traits viz., number of sympodia per plant (17.8) and number of bolls per plant (22.3).

The next best genotype RIL 203 for kapas yield $(135.63 \mathrm{~g})$ recorded higher boll weight $(5.25 \mathrm{~g})$, lint index (6.98) and ginning outturn (38.98\%) than other entries. RIL 44 was the topper for positive and significantly correlated trait viz., plant height $(136.1 \mathrm{~cm})$, and least value for negative and significantly correlated trait number of monopodia (0.3). It was next best to RIL 203 for boll weight (5.2), lint index (6.28) and GOT (36.27\%). RIL 122 (22.5) was on par with RIL 220 for number of bolls per plant. Kencharaddi et al., (2013) identified superior transgressive segregants in early segregating generation. They identified four promising segregants as they had desirable traits together viz., number of bolls per plant and seed cotton yield.

Regarding fibre quality traits, transgressive segregants for Upper half mean length, bundle strength and fibre fineness are compared for their other fibre component traits and presented in Tables 5, 6 and 7. Five transgressive segregants viz., RIL220, RIL63, RIL80, RIL157 and RIL185 exhibited extra long and fine fibres. Among them, RIL 63 alone exhibited good uniformity index (83.8) and good bundle strength $(28.37 \mathrm{~g} / \mathrm{tex})$. Other RILs were either average or good for one of these two traits. For bundle strength, the RILs 82, 43, 83, 190, 63, 120, 185 and 1 scored high compared to both parents which had weak fibres but all had fine fibres.

Except RIL 63 and 185 (extra long), all entries had long fibres. The uniformity ratio was excellent in RIL 43 and RIL 1. Considering the trait fibre fineness, seven RILs viz., 64, 56, 79, 42, 66, 209 and 80 could be identified, among which, the former two possess very fine fibres $(2.73$ and $2.88 \mu \mathrm{g} / \mathrm{inch}$ respectively). The fibres of all these genotypes had average bundle strength and long upper half mean length with the exception of RIL 80 with extra long fibres. The uniformity ratio was excellent in RIL 209 while others fall in either good or average category.

In Table 8 and Figure 1, superior transgressive segregants for yield and quality traits were compared with the original parents MCU 5 and TCH 1218. For nine yield and yield components, the male parent TCH 1218 was superior for five traits viz., plant height, number of sympodia per plant, boll weight, single plant yield and ginning outturn. The number of segregants in descending order for the traits is as follows viz., 201 for number of sympodia per plant, 185 for number of monopodia per plant, 165 for ginning outturn, 155 for single plant yield, 153 for lint index, 152 for boll number, 139 for boll weight and 93 for plant height and seed index. For five fibre quality traits, the parent MCU 5 is superior for all traits except elongation percent. 
Table.1 Genetic variability in recombinant inbred lines of cotton

\begin{tabular}{|c|c|c|c|c|c|c|c|}
\hline \multicolumn{2}{|c|}{ Character } & $F$ ratio & CD at $5 \%$ & GCV $(\%)$ & $\operatorname{PCV}(\%)$ & Heritability (\%) & GAM (\%) \\
\hline \multicolumn{2}{|c|}{ PH } & $6.16^{* *}$ & 11.86 & 8.08 & 9.52 & 72.08 & 1.05 \\
\hline \multicolumn{2}{|c|}{ NS } & $40.25^{* *}$ & 0.69 & 10.20 & 10.46 & 95.15 & 12.58 \\
\hline \multicolumn{2}{|c|}{ NM } & $163.23^{* *}$ & 0.09 & 54.29 & 55.95 & 98.78 & 255.69 \\
\hline \multicolumn{2}{|c|}{ NB } & $9.34^{* * *}$ & 2.75 & 18.95 & 21.1 & 80.66 & 9.87 \\
\hline \multicolumn{2}{|c|}{ BW } & $26.38^{* *}$ & 0.32 & 12.75 & 13.24 & 92.70 & 39.78 \\
\hline \multicolumn{2}{|c|}{ SPY } & $5.57^{* *}$ & 18.53 & 15.26 & 18.3 & 69.55 & 1.28 \\
\hline \multicolumn{2}{|c|}{ SI } & $151.57^{* *}$ & 0.23 & 9.42 & 9.48 & 98.69 & 19.02 \\
\hline \multicolumn{2}{|c|}{$\mathbf{L I}$} & $12.14^{* *}$ & 0.56 & 12.19 & 13.24 & 84.78 & 28.96 \\
\hline \multicolumn{2}{|c|}{ GOT } & $19.52^{* *}$ & 1.72 & 7.76 & 8.17 & 90.26 & 5.14 \\
\hline \multicolumn{2}{|c|}{ UHML } & $70.43^{* *}$ & 0.56 & 4.14 & 4.27 & 94.20 & 6.45 \\
\hline \multicolumn{2}{|c|}{ UI } & $4134.94^{* *}$ & 0.03 & 4.78 & 4.84 & 99.99 & 4.84 \\
\hline \multicolumn{2}{|c|}{ BS } & $929.50^{* *}$ & 0.08 & 6.78 & 6.86 & 99.94 & 8.82 \\
\hline \multicolumn{2}{|c|}{ EP } & $75.66^{* *}$ & 0.02 & 1.21 & 1.23 & 97.94 & 34.02 \\
\hline \multicolumn{2}{|c|}{ FF } & $86.56^{* *}$ & 0.13 & 11.14 & 11.41 & 95.39 & 49.07 \\
\hline PH & - & \multicolumn{2}{|c|}{ Plant height $(\mathrm{cm})$} & LI & - & \multicolumn{2}{|l|}{ Lint index } \\
\hline NS & - & \multicolumn{2}{|c|}{ Number of sympodia per plant } & GOT & - & \multicolumn{2}{|c|}{ Ginning outturn (\%) } \\
\hline NM & - & \multicolumn{2}{|c|}{$\begin{array}{l}\text { Number of monopodia per } \\
\text { plant }\end{array}$} & UHML & - & \multicolumn{2}{|c|}{$\begin{array}{l}\text { Upper half mean length } \\
\qquad(\mathrm{mm})\end{array}$} \\
\hline NB & - & \multicolumn{2}{|c|}{ Number of bolls per plant } & UI & - & \multicolumn{2}{|c|}{ Uniformity index (\%) } \\
\hline BW & - & \multicolumn{2}{|c|}{ Boll weight (g) } & BS & - & \multicolumn{2}{|c|}{ Bundle strength (g/tex) } \\
\hline SPY & - & \multicolumn{2}{|c|}{ Single plant yield (g) } & EP & - & \multicolumn{2}{|c|}{ Elongation percent } \\
\hline SI & - & \multicolumn{2}{|c|}{ Seed index } & FF & - & \multicolumn{2}{|c|}{ Fibre fineness $(\mu \mathrm{g} /$ inch $)$} \\
\hline
\end{tabular}

Table.2 Correlation coefficients between yield and yield related traits among RIL population in cotton

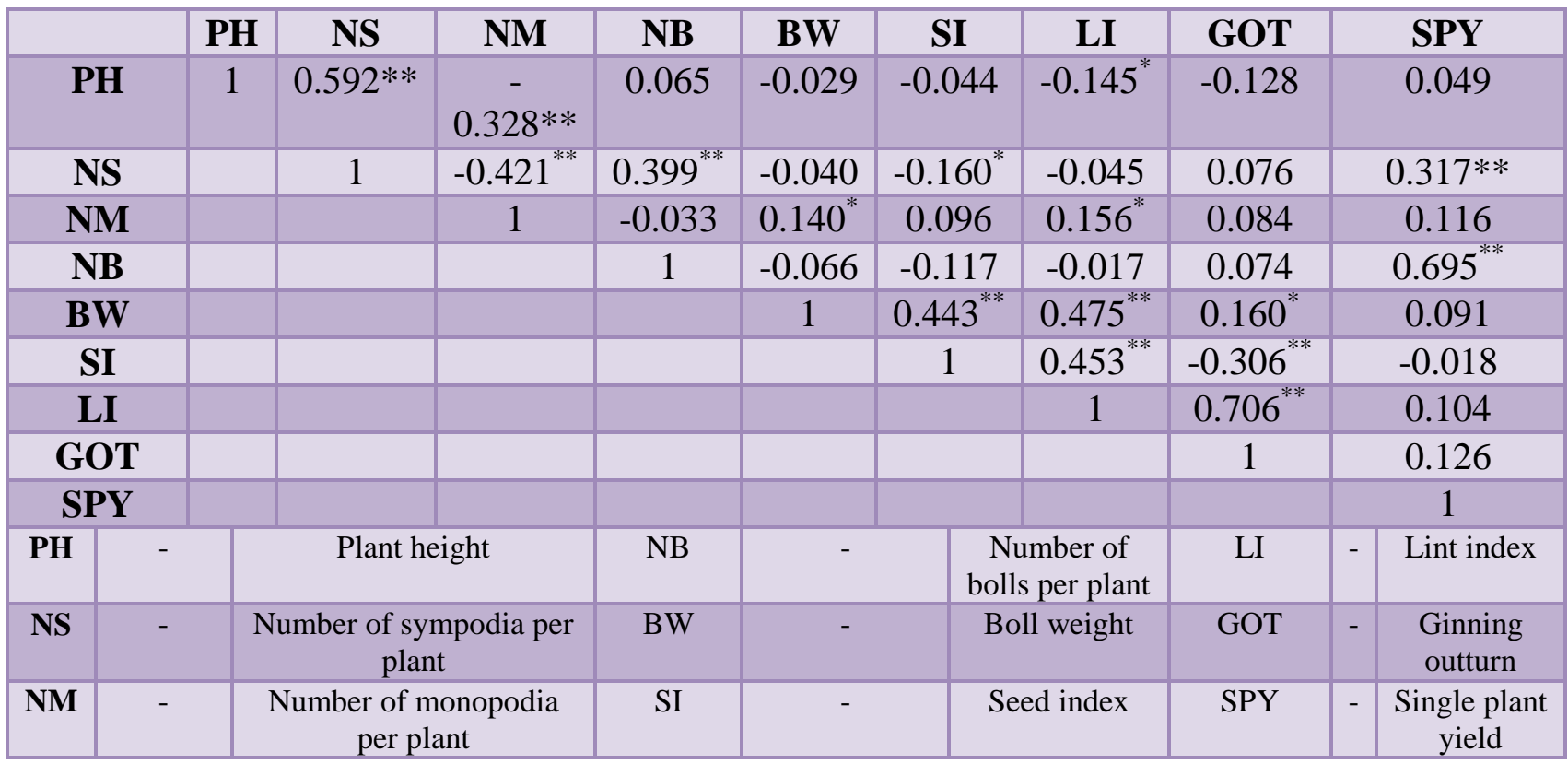


Table.3 Correlation coefficients between upper half mean length and fibre related traits among RIL population in cotton

\begin{tabular}{|c|c|c|c|c|c|}
\hline & UR & BS & EP & FF & UHML \\
\hline UR & 1 & $0.232^{* *}$ & $0.172^{*}$ & -0.060 & 0.014 \\
\hline BS & & 1 & $0.567^{* *}$ & $-0.369^{* *}$ & $0.389^{* *}$ \\
\hline EP & & & 1 & 0.060 & $0.325^{* *}$ \\
\hline FF & & & & 1 & $-0.172^{*}$ \\
\hline UHML & & & & 1 \\
\hline UR & - & Uniformity ratio & FF & - & $\begin{array}{c}\text { Fibre fineness } \\
(\mu \mathrm{g} / \text { inch) }\end{array}$ \\
\hline BS & - & Bundle strength (g/tex) & UHML & - & $\begin{array}{c}\text { Upper Half mean } \\
\text { length }(\mathrm{mm})\end{array}$ \\
\hline EP & - & Elongation percentage & & & \\
\hline
\end{tabular}

Table.4 Transgressive segregants for single plant yield over superior parent TCH 1218 in cotton

\begin{tabular}{|c|c|c|c|c|c|c|c|c|c|c|c|}
\hline & RIL No. & SPY & \multicolumn{2}{|c|}{ PH } & NM & NS & NB & BW & SI & LI & GOT \\
\hline & 220 & 149.36 & \multicolumn{2}{|c|}{121.50} & 0.70 & 17.80 & 22.30 & 4.77 & 10.19 & 5.83 & 36.40 \\
\hline & 203 & 135.63 & \multicolumn{2}{|c|}{123.50} & 0.80 & 15.70 & 21.80 & 5.25 & 10.95 & 6.98 & 38.98 \\
\hline & 42 & 132.76 & \multicolumn{2}{|c|}{122.50} & 0.80 & 15.40 & 17.30 & 4.43 & 11.27 & 5.09 & 31.22 \\
\hline & 122 & 131.54 & \multicolumn{2}{|c|}{131.60} & 0.70 & 16.90 & 22.50 & 4.38 & 10.21 & 5.19 & 33.67 \\
\hline & 44 & 130.47 & \multicolumn{2}{|c|}{136.10} & 0.30 & 17.20 & 20.40 & 5.20 & 11.08 & 6.28 & 36.27 \\
\hline & MCU 5 & 80.69 & \multicolumn{2}{|c|}{109.90} & 1.30 & 12.70 & 13.60 & 4.45 & 10.86 & 5.25 & 32.62 \\
\hline & TCH1218 & 85.50 & \multicolumn{2}{|c|}{123.40} & 1.40 & 12.90 & 12.60 & 4.46 & 8.58 & 4.17 & 32.76 \\
\hline \multicolumn{2}{|c|}{$\begin{array}{l}\text { Highest value recorded } \\
\text { among } 220 \text { RILs }\end{array}$} & 149.36 & \multicolumn{2}{|c|}{143.90} & 0.00 & 18.80 & 25.43 & 6.08 & 13.26 & 7.74 & 42.42 \\
\hline PH & - & Plant h & (cm) & NB & - & $\begin{array}{r}\text { Number o } \\
\text { pla }\end{array}$ & $\begin{array}{l}\text { f bolls per } \\
\text { int }\end{array}$ & & I & - & Lint index \\
\hline NS & - & $\begin{array}{r}\text { Number } \\
\text { per }\end{array}$ & odia & BW & - & Boll we & ight (g) & & OT & - & $\begin{array}{l}\text { Ginning } \\
\text { outturn }(\%)\end{array}$ \\
\hline NM & - & $\begin{array}{r}\text { Nur } \\
\text { monopoc }\end{array}$ & f plant & SI & - & Seed & index & & PY & - & $\begin{array}{l}\text { Single plant } \\
\text { yield }(\mathrm{g})\end{array}$ \\
\hline
\end{tabular}

Table.5 Transgressive segregants for Upper half mean length of fibre over superior parent MCU 5 in cotton

\begin{tabular}{|c|c|c|c|c|c|}
\hline RIL No. & $\begin{array}{c}\text { UHML } \\
(\mathbf{m m})\end{array}$ & $\begin{array}{c}\text { UI } \\
(\boldsymbol{\%})\end{array}$ & $\begin{array}{c}\text { BS } \\
(\mathbf{g} / \mathbf{t e x})\end{array}$ & $\begin{array}{c}\text { EP } \\
(\mathbf{\%})\end{array}$ & $\begin{array}{c}\text { FF } \\
(\boldsymbol{\mu g} / \mathbf{i n c h})\end{array}$ \\
\hline $\mathbf{2 2 0}$ & 34.52 & 81.30 & 28.70 & 5.93 & 3.65 \\
\hline $\mathbf{6 3}$ & 34.10 & 83.80 & 29.37 & 5.93 & 3.36 \\
\hline $\mathbf{8 0}$ & 33.58 & 84.70 & 28.90 & 5.87 & 3.06 \\
\hline $\mathbf{1 5 7}$ & 33.47 & 83.50 & 28.30 & 5.93 & 3.50 \\
\hline $\mathbf{1 8 5}$ & 33.27 & 81.80 & 29.20 & 6.03 & 3.55 \\
\hline MCU 5 & 32.95 & 83.30 & 28.83 & 5.90 & 3.49 \\
\hline TCH1218 & 30.45 & 82.50 & 28.30 & 5.97 & 3.78 \\
\hline
\end{tabular}


Table.6 Transgressive segregants for bundle strength over superior parent MCU 5 in cotton

\begin{tabular}{|c|c|c|c|c|c|}
\hline RIL No. & $\begin{array}{c}\text { BS } \\
(\mathbf{g} / \text { tex })\end{array}$ & $\begin{array}{c}\text { UI } \\
(\mathbf{\%})\end{array}$ & $\begin{array}{c}\text { UHML } \\
(\mathbf{m m})\end{array}$ & $\begin{array}{c}\text { EP } \\
(\mathbf{\%})\end{array}$ & $\begin{array}{c}\text { FF } \\
(\boldsymbol{\mu g} / \mathbf{i n c h})\end{array}$ \\
\hline $\mathbf{8 2}$ & 29.83 & 84.50 & 31.91 & 5.97 & 3.26 \\
\hline $\mathbf{4 3}$ & 29.63 & 85.60 & 27.64 & 6.00 & 3.52 \\
\hline $\mathbf{8 3}$ & 29.43 & 84.60 & 31.18 & 5.97 & 3.48 \\
\hline $\mathbf{1 9 0}$ & 29.43 & 83.10 & 31.39 & 6.03 & 3.79 \\
\hline $\mathbf{6 3}$ & 29.37 & 83.80 & 34.10 & 5.93 & 3.36 \\
\hline $\mathbf{1 2 0}$ & 29.27 & 82.90 & 30.04 & 5.93 & 3.39 \\
\hline $\mathbf{1 8 5}$ & 29.20 & 81.80 & 33.27 & 6.03 & 3.55 \\
\hline $\mathbf{1}$ & 29.10 & 85.10 & 29.31 & 6.07 & 3.41 \\
\hline MCU 5 & 23.07 & 83.30 & 32.95 & 5.90 & 3.49 \\
\hline TCH1218 & 22.64 & 82.50 & 30.45 & 5.97 & 3.78 \\
\hline
\end{tabular}

Table.7 Transgressive segregants for fibre fineness over superior parent MCU 5 in cotton

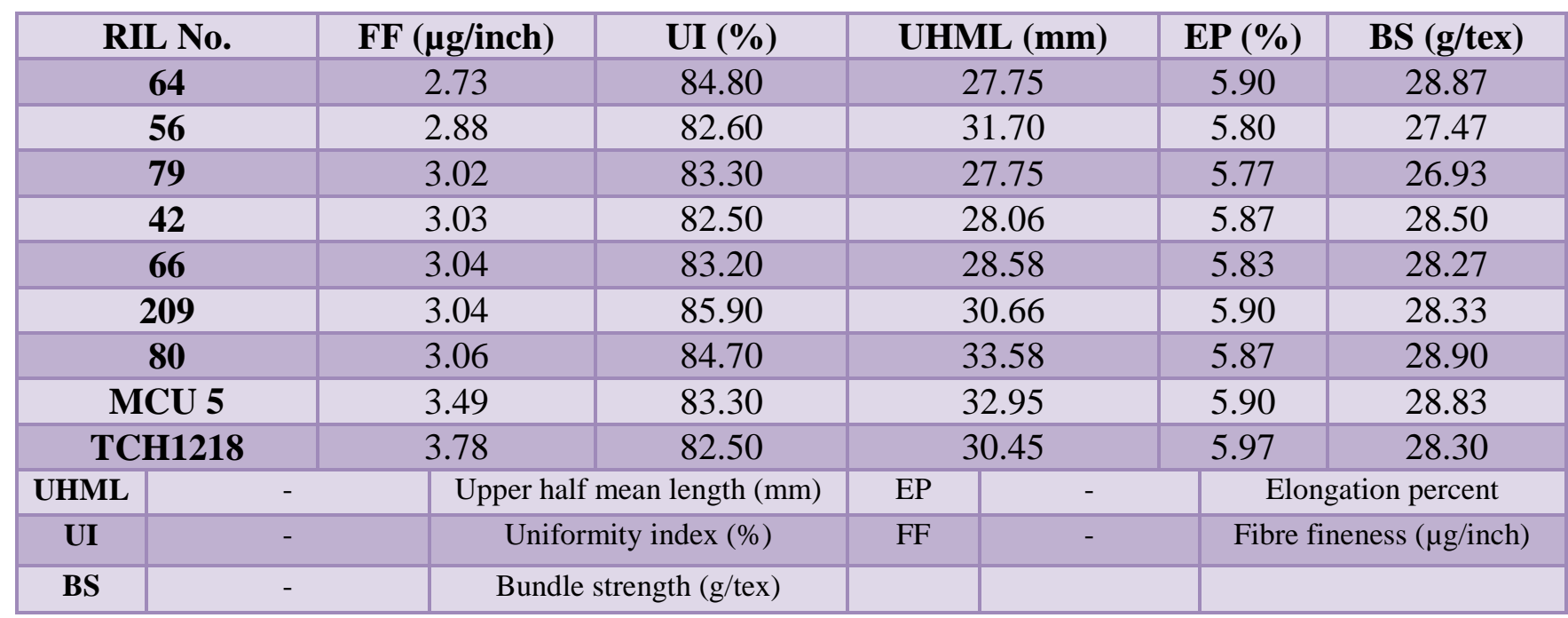

Fig.1 Percentage of superior transgressive segregants for yield and fibre quality traits in RIL population of cross MCU $5 \times \mathrm{TCH} 1218$ in comparison to respective superior parent

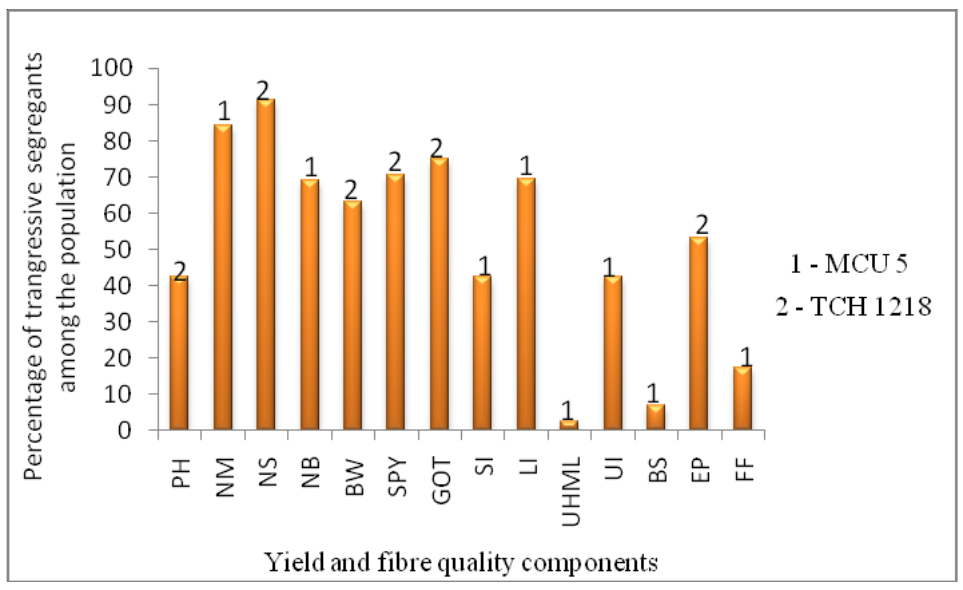


Table.8 Transgressive segregants in recombinant inbred lines of cross MCU 5 x TCH 1218 in cotton

\begin{tabular}{|c|c|c|c|c|c|c|c|c|c|}
\hline & Traits & $\begin{array}{c}\text { No. of favouarable } \\
\text { transgressive } \\
\text { segregants }\end{array}$ & \multicolumn{3}{|c|}{$\begin{array}{c}\text { Range of the } \\
\text { transgressive } \\
\text { segregants }\end{array}$} & $\begin{array}{l}\text { Genotype with } \\
\text { highest value } \\
\text { (RIL No) }\end{array}$ & \multicolumn{3}{|c|}{ Superior parent } \\
\hline & PH & 93 & \multicolumn{3}{|c|}{$123.5-143.90$} & 96 & \multicolumn{3}{|c|}{ ТCH 1218 (123.40) } \\
\hline & NM & 185 & \multicolumn{3}{|c|}{$0-1.20$} & 74 & \multicolumn{3}{|c|}{ MCU 5 (1.30) } \\
\hline & NS & 201 & \multicolumn{3}{|c|}{$13.00-18.80$} & 93,56 & \multicolumn{3}{|c|}{ ТCH 1218 (12.90) } \\
\hline & NB & 152 & \multicolumn{3}{|c|}{$13.70-25.43$} & 217 & \multicolumn{3}{|c|}{ MCU5 (13.60) } \\
\hline & BW & 139 & \multicolumn{3}{|c|}{$4.47-6.08$} & 59 & \multicolumn{3}{|c|}{ TCH1218 (4.46) } \\
\hline & SPY & 155 & \multicolumn{3}{|c|}{$85.59-149.36$} & 220 & \multicolumn{3}{|c|}{ ТCH 1218 (85.50) } \\
\hline & GOT & 165 & \multicolumn{3}{|c|}{$32.80-45.46$} & 27 & \multicolumn{3}{|c|}{ TCH1218 (32.73) } \\
\hline & SI & 93 & \multicolumn{3}{|c|}{$10.88-13.26$} & 180 & \multicolumn{3}{|c|}{ MCU5 (10.86) } \\
\hline & $\mathbf{L I}$ & 153 & \multicolumn{3}{|c|}{$5.26-7.85$} & 153 & \multicolumn{3}{|c|}{ MCU5 (5.25) } \\
\hline & UHML & 5 & \multicolumn{3}{|c|}{$33.27-34.52$} & 220 & \multicolumn{3}{|c|}{ MCU5 (32.95) } \\
\hline & UI & 93 & \multicolumn{3}{|c|}{$83.40-87.80$} & 140 & \multicolumn{3}{|c|}{ MCU5 (83.30) } \\
\hline & BS & 15 & \multicolumn{3}{|c|}{$28.87-29.83$} & 82 & \multicolumn{3}{|c|}{ MCU5 (28.83) } \\
\hline & EP & 117 & \multicolumn{3}{|c|}{$5.90-6.07$} & 1 & \multicolumn{3}{|c|}{ TCH1218 (5.97) } \\
\hline & FF & 38 & \multicolumn{3}{|c|}{$2.73-3.48$} & 64 & \multicolumn{3}{|c|}{ MCU 5(3.49) } \\
\hline PH & - & Plant height $(\mathrm{cm})$ & SPY & - & & ingle plant yield $(\mathrm{g})$ & UI & - & Uniformity \\
\hline NM & - & $\begin{array}{c}\text { Number of monopodia per } \\
\text { plant }\end{array}$ & GOT & - & & Ginning outturn (\%) & BS & - & Bundle strengt \\
\hline NS & - & $\begin{array}{l}\text { Number of sympodia per } \\
\text { plant }\end{array}$ & SI & - & & Seed index & EP & - & Elongation per \\
\hline NB & - & Number of bolls per plant & LI & - & & Lint index & FF & - & Fibre fineness ( \\
\hline BW & - & Boll weight $(\mathrm{g})$ & UHML & - & Upp & $\mathrm{r}$ half mean length (mm) & & & \\
\hline
\end{tabular}

Fig.2 Percentage of superior segregants for yield and fibre quality traits in RIL population of crosses MCU $5 \times$ TCH 1218 in comparison to respective superior check

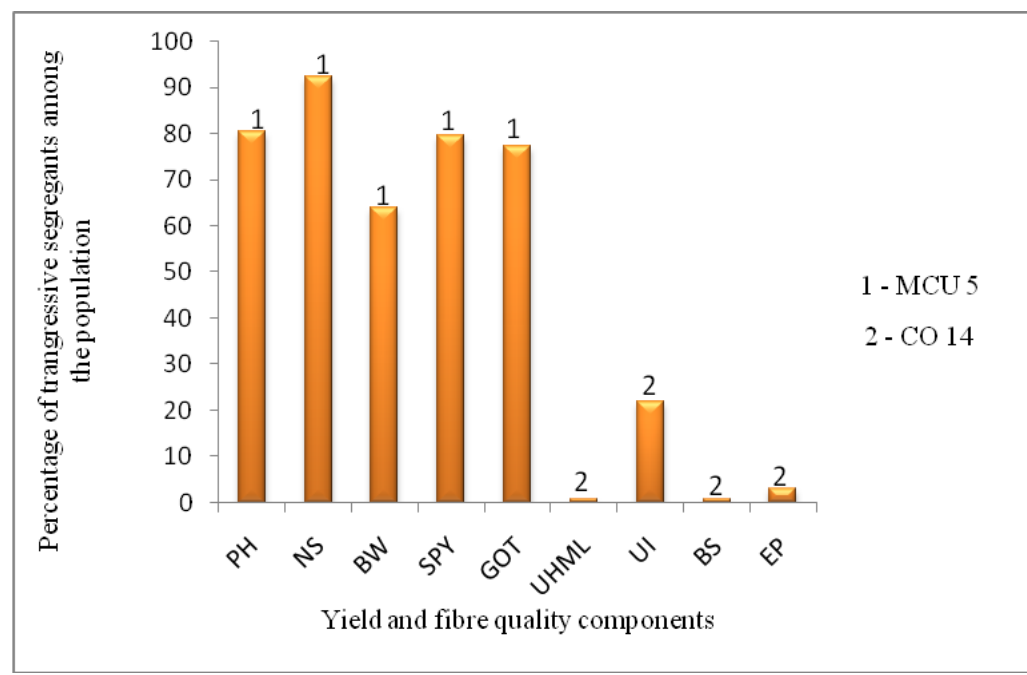


Table.9 Segregants performed better than check variety in recombinant inbred lines of cross MCU $5 \times$ TCH 1218 in cotton

\begin{tabular}{|c|c|c|c|c|}
\hline Traits & $\begin{array}{c}\text { No. of } \\
\text { favouarable } \\
\text { transgressive } \\
\text { segregants }\end{array}$ & $\begin{array}{c}\text { Range of the } \\
\text { transgressive } \\
\text { segregants }\end{array}$ & $\begin{array}{c}\text { Genotype with } \\
\text { highest value (RIL } \\
\text { No) }\end{array}$ & $\begin{array}{c}\text { Superior } \\
\text { check }\end{array}$ \\
\hline PH & 177 & $123.5-143.90$ & 96 & MCU 5 \\
& & $13.00-18.80$ & 93,56 & $\begin{array}{c}\text { MCU 5 } \\
(12.70)\end{array}$ \\
\hline NS & 203 & $4.47-6.08$ & 59 & MCU 5 (4.45) \\
\hline BW & 141 & $85.59-149.36$ & 220 & MCU 5 \\
\hline SPY & 175 & $32.80-45.46$ & 27 & MCU 5 \\
\hline & & & & $(32.59)$ \\
\hline GOT & 170 & $33.27-34.52$ & 220 & CO 14 (34.20) \\
\hline UHML & 2 & $83.40-87.80$ & 140 & CO 14 (84.10) \\
\hline UI & 48 & $28.87-29.83$ & 82 & CO 14 (29.55) \\
\hline BS & 2 & $5.90-6.07$ & 1 & MCU 5 (3.49) \\
\hline EP & 7 & & & \\
\hline
\end{tabular}

**For four traits MCU 5 was superior parent and values of Table 6 are applicable.

In general, the number of favourable segregants is lower for quality traits when compared to yield traits in the population. For upper half mean length and bundle strength, only 5 and 15 RILs were superior in performance compared to MCU 5 which constitutes 2.5 and 6.8 per cent of the material studied. In the whole population, 17.2 and 42.3 per cent of the lines had desirable fibre fineness and uniformity index. Kumar et al., (2018) evaluated $F_{2}$ population for yield and fibre quality traits. In combination of seed cotton yield and GOT with 50 and 5 percentage of advantage over superior parent 14 transgressive segregants were identified. Another 14 transgressive segregants had 3 per cent advantage over superior parent for bundle strength. This confirms that percentage of favourable lines is lesser for fibre quality traits.

The variety MCU 5 is one of the parent and incidentally a standard check variety still in cultivation. So in our study, MCU 5 and the latest variety $\mathrm{CO} 14$ were considered as checks. The variety CO 14 was superior for four fibre quality traits viz., upper half mean length, uniformity index, bundle strength and elongation percentage (Table 9). The number of desirable segregants were more for uniformity index (48) and very low for other traits which ranged from 2 to 7 . On comparison with MCU 5, the highest number of segregants (92.3\%) was noticed for number of sympodia per plant, followed by plant height $(80.5 \%)$. For single plant yield and ginning outturn, the values were closer to each other $(79.5 \%$ and $77.3 \%$ respectively). For boll weight, $64 \%$ of the lines were superior (Fig. 2).

High heritability with high to moderate GAM was exhibited by number of sympodia per plant, number of monopodia per plant, boll weight, seed index, lint index, elongation percentage and fibre fineness. These traits were additive in nature and selection will be effective. Superior transgressive segregants 
for single plant yield was identified as RIL 44 as it performed better for other yield component traits, while for fibre quality traits RIL 63 performance was comparatively high.

Among the population RIL 220 ranked top for single plant yield and upper half mean length. Fibre quality traits had few favourable segregants when compared to yield traits.

Isolated RIL can be used in advance breeding trial for varietal development.

\section{References}

Ahsan, M. Z., Majidano, M. S., Bhutto, H., Soomro, A. W., Panhwar, F. H., Channa, A. R., and Sial, K. B. (2015). Genetic variability, coefficient of variance, heritability and genetic advance of some Gossypium hirsutum L. accessions. Journal of Agricultural Science, 7(2), 147.

Alkuddsi, Y., Patil, S. S., Manjula, S. M., Patil, B. C., Nadaf, H. L., and Nandihali, B. S. (2013). Genetic Variability Studies in Segregating Generation of Gossypium barbadense lines in cotton. Molecular Plant Breeding, 4.

Deshmukh, M. R., Deosarkar, D. B., Deshmukh, J. D., and Chinchane, V. N. (2019). Correlation and path coefficient analysis of yield contributing and fiber quality traits in Desi cotton (Gossypium arboreum L.). IJCS, 7(3), 585-589.

Erande, C. S., Kalpande, H. V., Deosarkar, D. B., Chavan, S. K., Patil, V. S., Deshmukh, J. D. and Puttawar, M. R. (2014). Genetic variability, correlation and path analysis among different traits in desi cotton (Gossypium arboreum L.). African Journal of Agricultural Research,9(29), 22782286.
Farooq, J., Rizwan, M., Saleem, S., Sharif, I., Chohan, S. M., Riaz, M. and Kainth, R. A. (2018). Determination of genetic variation for earliness, yield and fiber traits in advance lines of cotton (Gossypium hirsutum). Advances in Agricultural Sciences, 6(2), 59-74.

Haq, A. U., Khan, N. U., Raza, H., Gul, S., Akbar, S., Khan, S. U. and Khan, S. M. (2017). Genetic attributes of $F_{3}$ populations and their parental lines in upland cotton. JAPS: Journal of Animal and Plant Sciences, 27(2).

Jarwar, A. H., Wang, X., Iqbal, M. S., Sarfraz, Z., Wang, L., Ma, Q. and Shuli, F. (2019). Genetic divergence on the basis of principal component, correlation and cluster analysis of yield and quality traits in cotton cultivars. Pakistan journal of botany, 51(3), 1143-1148.

Kale, U. V., Kalpande, H. V., Annapurve, S. N., and Gite, V. K. (2007). Yield components analysis in American cotton (Gossypium hirsutum L.). Madras Agric. J, 94(7-12), 156161.

Kencharaddi, H. G., Patil, R. S., Mohan, N. B., Praveenkumar, B., Kumar, K. Y., and Chowkimath, A. (2013). Identification of superior segregants in early segregating generations of upland cotton (Gossypium hirsutum 1.). Plant Archives, 13(1), 45-49.

Khan, U. Q., Cantrell, R. G., and Steiner, R. (2003). Genetic variability for maturity characteristics in narrow rows cotton. Sarhad Journal of Agriculture (Pakistan).

Killi, F. A. T. İ. H., Efe, L. A. L. E., and Mustafayev, S. E. F. E. R. (2005). Genetic and environmental variability in yield, yield components and lint quality traits of cotton. Int. J. Agri. Biol, 7(6), 1007-1010.

Kumar, N. M., Katageri, I. S., Kumar, G. S., 
and Gowda, S. A. (2018). Transgressive Segregation for Fibre Quality, Seed Cotton Yield and Its Component Traits in Gossypium barbadense L. Cotton. Int. J. Curr. Microbiol. App. Sci, 7(1), 1040-1051.

Larik, A. S., Ansari, S. R., and Kumbhar, M. B. (1997). Heritability analysis of yield and quality components in Gossypium hirsutum L.Pakistan Journal of Botany (Pakistan).

Monisha, K., Premalatha, N., Sakthivel, N., and Kumar, M. (2018). Research Article Genetic variability and correlation studies in upland cotton (Gossypium hirsutum. L). Electronic Journal of Plant Breeding, 9(3), 10531059.

Preetha, S., and Raveendran, T. S. (2007).
Genetic variability and association analysis in three different morphological groups of cotton (Gossypium hirsutum L.). Asian Journal of plant sciences, 6(1), 122128.

Pujer, S., Siwach, S. S., Deshmukh, J., Sangwan, R. S., and Sangwan, O. (2014). Research note genetic variability, correlation and path analysis in upland cotton (Gossypium hirsutum L.). Electronic Journal of Plant Breeding, 5(2), 284-289.

Raza, H., Khan, N. U., Khan, S. A., Gul, S., Latif, A., Hussain, I. and Baloch, M. (2016). Genetic variability and correlation studies in $\mathrm{F}_{4}$ populations of upland cotton. J. Anim. Plant Sci, 26(4), 1048-1055.

\section{How to cite this article:}

Nandhini, K., N. Premalatha, R. Saraswathi, N. Sakthivel and Kumaravadivel, N. 2019. Genetic Studies for Yield and Fibre Quality Related Traits in Upland Cotton (Gossypium hirsutum L.) and Identification of Superior Transgressive Segregants. Int.J.Curr.Microbiol.App.Sci. 8(11): 1609-1619. doi: https://doi.org/10.20546/ijcmas.2019.811.186 